\title{
EFEKTIVITAS YOUTUBE SEBAGAI MEDIA PEMBELAJARAN JARAK JAUH (PJJ) MATA PELAJARAN PPKN PADA MASA PANDEMI COVID-19
}

\author{
INDRIYATI \\ MAN 1 banyumas \\ e-mail: indriyatidjatmiko372@gmail.com
}

\begin{abstract}
ABSTRAK
Pandemi Covid-19 telah melanda dunia pada umumnya, dan Indonesia pada khususnya, sangat berdampak terhadap berbagai aspek kehidupan berbangsa dan bernegara, termasuk dunia pendidikan. Pembelajaran tatap muka di dalam kelas, terpaksa harus diubah menjadi pembelajaran jarak jauh melalui berbagai media online dalam rangka menghentikan penularan Covid-19. Media pembelajaran online yang digunakan untuk proses pembelajaran jarak jauh antara lain, zoom, google meet, google classroom, whatsap, elearning, youtube, dan lain- lain. Pembelajaran jarak jauh menuntut pendidik untuk selalu berkreasi dan berinovasi mengembangkan media pembelajaran yang afektif dan efisien, sehingga tujuan pembelajaran tercapai. Penulis sebagai guru PPKn membuat penelitian yang berjudul, "Efektivitas Youtube sebagai Media Pembelajaran Jarak Jauh (PJJ) Mata Pelajaran PPKn pada Masa Pandemi Covid19. Youtube memiliki keunggulan karena sangat digemari oleh semua lapisan masyarakat Indonesia, krena kehadiran kreator dengan konten yang bervariasi . Youtube berisi konten video yang bersifat audio visual sehingga pesan-pesan yang termuat di dalam konten tersebut sangat mudah diterima oleh pengguna atau penonton. Penelitian ini bertujuan untuk mengetahui efektivitas youtube sebagai media pembelajaran jarak jauh pada mata pelajaran PPKn. Penelitian ini menggunakan kuesioner model secara acak. Jawaban responden penelitian menunjukkan bahwa youtube afektif sebagai media pembelajaran jarak jauh pada mata pelajaran PPKn.
\end{abstract}

Kata Kunci: Youtube media PPKn, Media PJJ Youtube, PJJ PPKn

\section{PENDAHULUAN}

Seluruh warga dunia dikejutkan dengan munculnya virus dari Wuhan China yang sangat mudah menular dan menginfeksi manusia, yang selanjutnya lebih dikenal dengan sebutan Covid-19. Karena sifatnya yang sangat mudah menular, dan penyebaran yang sangat cepat, serta menelan korban jiwa yang cukup banyak, maka untuk menghentikan penularan Covid-19 diperlukan cara yang tepat.

Covid 19 masuk ke Indonesia pada bulan Februari 2020. Perkembangan Covid-19 di Indonesia sangat cepat, maka untuk menghentikan penularan Covid-19 di Indonesia pemerintah mengambil kebijakan pembelajaran jarak jauh bagi pelajar dan mahasiswa. Kebijakan pembelajaran jarak jauh menuntut guru untuk berinovasi membuat media pembelajaran yang efektif dan efisien,

Pembelajaran jarak jauh dapat menggunakan bermacam-macam aplikasi untuk media pembelajaranBerbagai aplikasi antara lain, Zoom, Google Meet, Watshap, Instagram, Facebook, Telegram, Youtube, dan lain-lain. Masyarakat Indonesia, terutama pelajar sangat mengenal aplikasi Yotube.

Youtube merupakan aplikasi berbasis video yang bersifat audio dan visual. Guru dapat membuat video-video pembelajaran kemudian mengupload ke Channel Youtube dengan cara yang sangat mudah. Youtube memiliki keunggulan karena sangat digemari oleh semua lapisan masyarakat Indonesia. Hal ini disebabkan banyaknya bermunculan kreator dengan konten yang beraneka ragam. Memasukkan Youtube ke dalam dunia pendidikan tentu merupakan hal yang mudah. Youtube memudahkan peserta didik untuk mendownload video pembelajaran yang diupload guru, kemudian membagikan video tersebut kepada peserta didik lain.

Mata pelajaran PPKn wajib diajarkan di SD, SMP/MTs, dan SMA/MA/SMK. Pendidikan Pancasila dan Kewarganegaraan (PPKn) masuk kategori ilmu sosial. Pembelajaran 
jarak jauh untuk mata pelajaran Pendidkan Pancasila dan Kewarganegaran (PPKn) tentu menghadapi beberapa kendala, misalnya, peserta didik mudah bosan kalau hanya diberi tugas membaca buku atau lembar kerja siswa, peserta didik kurang terarah apabila hanya membaca secara mandiri.

Apabila kendala dalam pembelajaran jarak jauh pada mata pelajaran Pendidikan Pancasila dan Kewarganegaraan tidak segera diatasi, dikhawatirkan tujuan pembelajaran tidak tercapai secara optimal. Maka dalam pembelajaran jarak jauh mata pelajaran PPKn diperlukan media pembelajaran yang efektif dan efisien Berdasarkan uraian di atas penulis menyusun penelitian yang berjudul, "Efektivitas Youtube sebagai Media Pembelajaran Jarak Jauh (PJJ) Mata Pelajaran PPKn pada Masa Pandemi Covid-19".

Tujuan penelitian ini yaitu untuk mengetahui efektivitas Youtube sebagai media pembelajaran jarak jauh mata pelajaran PPKn pada masa pandemic Covid-19. Rumusan masalah pada penelitian ini , "Apakah Youtube efektif sebagai media pembelajaran jarak jauh pada mata pelajaran PPKn pada masa pandemi covid-19?"

Penelitian sebelumnya yang menjadi rujukan penulis antara lain, Moh. Arif Susanto, Elita Arcelina Sandi, membuat penelitian yang berjudul, Aktualisasi Bahasa Jawa Youtuber Upaya Mempertahankan Bahasa Jawa pada Masa Pandemi Covid-19, memperoleh hasil bahwa Youtube dapat mempertahankan Bahasa Jawa yang sebelumnya menggunakan media televise. Muhammad Yusi Kamhar, Erma Lestari, menulis penelitian yang berjudul, Pemanfaatan Sosial Media Youtube sebagai Media Pembelajaran Bahasa Indonesia di Perguruan Tinggi, memperoleh hasil bahwa Youtube efektif sebagai media pembelajaran Bahasa Indonesia di Perguruan Tinggi.

Berdasarkan hasil kedua penelitian di atas, bahwa Youtube efektif dalam mempertahankan Bahasa Jawa pada masa pandemi Covid-19, dan efektif sebagai media perkuliahan di Perguruan Tinggi pada mata kuliah Bahasa Indonesia, maka penulis meneliti efektivitas Youtube sebagai media pembelajaran PPKn pada masa pandemi Covid-19. Hipotesis penelitian, yaitu Youtube efektif sebagai media pembelajaran mata pelajaran PPKn pada masa pandemi Covid-19.

\section{METODE PENELITIAN}

Penelitian ini menggunakan kuesioner yang diberikan kepada pengunjung Channel Youtube BUNDA INDRI. Subjek penelitian adalah siswa SMA/MA/SMK yang berkunjung ke Channel BUNDA INDRI. Waktu yang digunakan untuk penelitian yaitu satu bulan, pada bulan Oktober sampai dengan bulan November 2020. Tahap persiapan penelitian dilaksanakan dalam satu minggu, tahap pengumpulan dan pengolahan data dilaksanakan dalam dua minggu, dan tahap penulisan satu minggu.

\section{HASIL DAN PEMBAHASAN}

\section{Hasil}

Hasil penelitian yang diperoleh dari pengolahan data dari lima puluh responden adalah sebagai berikut :

Tabel 1. Daftar Jawaban Responden Penelitian

\begin{tabular}{|r|l|c|c|}
\hline Nomor & \multicolumn{1}{|c|}{ Pertanyaan } & Ya & Tidak \\
\hline 1 & $\begin{array}{l}\text { Apakah media pembelajaran berbasis Youtube lebih menarik } \\
\text { dari media yang lainnya? }\end{array}$ & 40 & 10 \\
\hline 2 & $\begin{array}{l}\text { Apakah Youtube lebih membantu dalam memahami materi } \\
\text { pelajaran? }\end{array}$ & 45 & 5 \\
\hline 3 & $\begin{array}{l}\text { Apakah dengan menggunakan Youtube waktu belajar lebih } \\
\text { rileks atau santai? }\end{array}$ & 45 & 5 \\
\hline
\end{tabular}


Apakah dengan menonton video Youtube beban belajar

4 menjadi lebih ringan?

Berdasarkan tabel di atas dapat diuraikan bahwa 40 responden yang menjawab bahwa, media pembelajaran berbasis Youtube lebih menarik, sedangkan 20 orang menjawab tidak menarik. Jumlah responden yang menjawab bahwa Youtube membantu dalam memahami materi pelajaran sebanyak 45 orang, sedangkan yang menjawab tidak membantu dalam memahami materi pelajaran 5 orang.

Responden yang menjawab bahwa dengan menggunakan youtube waktu belajar lebih rileks atau santai berjumlah 45 orang, sedangkan yang menjawab bahwa Youtube tidak membuat waktu belajar lebih rileks atau santai berjumlah 5 orang. Youtube membuat beban belajar lebih ringan disetujui oleh 46 responden, sedangkan yang tidak menyetujui berjumlah 4 orang.

Tabel 2. Prosentase Jawaban Responden

\begin{tabular}{|r|l|c|c|}
\hline Nomor & \multicolumn{1}{|c|}{ Pertanyaan } & Ya & Tidak \\
\hline 1 & $\begin{array}{l}\text { Apakah media pembelajaran berbasis Youtube lebih menarik } \\
\text { dari media yang lainnya? }\end{array}$ & $80 \%$ & $20 \%$ \\
\hline 2 & $\begin{array}{l}\text { Apakah Youtube lebih membantu dalam memahami materi } \\
\text { pelajaran? }\end{array}$ & $90 \%$ & $10 \%$ \\
\hline 3 & $\begin{array}{l}\text { Apakah dengan menggunakan Youtube waktu belajar lebih } \\
\text { rileks atau santai? }\end{array}$ & $90 \%$ & $10 \%$ \\
\hline 4 & $\begin{array}{l}\text { Apakah dengan menonton video Youtube beban belajar } \\
\text { menjadi lebih ringan? }\end{array}$ & $92 \%$ & $8 \%$ \\
\hline
\end{tabular}

Berdasarkan tabel prosentase hasil penelitian di atas dapat diuraikan sebagai berikut. Penggunaan media Youtube dalam pembelajaran PPKn menarik bagi peserta didik. Responden yang menjawab bahwa media pembelajaran berbasis youtube lebih menarik jumlah prosentase $80 \%$, sedangkan yang menjawab tidak menarik hanya $20 \%$. Youtube sangat membantu peserta didik dalam memahami materi pelajaran. Prosentase responden yang menjawab bahwa Youtube membantu memahami pelajaran $90 \%$, sedangkan yang menjawab tidak membantu memahami pelajaran $10 \%$.

Pembelajaran menggunakan media Youtube membuat peserta didik lebih rileks atau santai dalam menggunakan waktu belajar. Prosentase responden yang menjawab bahwa youtube membuat waktu belajar lebih rileks atau santai $90 \%$, sedangkan yang menyatakan bahwa Youtube tidak membuat waktu belajar lebih rileks atau santai berjumlah 10\%. Media Youtube dapat meringankan beban belajar peserta didik. Hal ini ditunjukkan jawaban responden yang menyatakan bahwa dengan menonton video Youtube dalam pembelajaran PPKn beban belajar menjadi lebih ringan berjumlah 92\%, sedangkan yang menjawab tidak hanya $8 \%$.

\section{Pembahasan}

Hasil penelitian bahwa Youtube efektif sebagai media pembelajaran mata pelajaran PPKn pada masa pandemi Covid-19 sesuai dengan hasil penelitian sebelumnya. Moh. Arif Susanto, Elita Arcelina Sandi, membuat penelitian yang berjudul, Aktualisasi Bahasa Jawa Youtuber Upaya Mempertahankan Bahasa Jawa pada Masa Pandemi Covid-19, memperoleh 
hasil bahwa Youtube dapat mempertahankan Bahasa Jawa yang sebelumnya menggunakan media televisi.

Muhammad Yusi Kamhar, Erma Lestari, menulis penelitian yang berjudul, Pemanfaatan Sosial Media Youtube sebagai Media Pembelajaran Bahasa Indonesia di Perguruan Tinggi, memperoleh hasil bahwa Youtube efektif sebagai media pembelajaran Bahasa Indonesia di Perguruan Tinggi. dimaksudkan untuk memaknai hasil penelitian sesuai dengan teori yang digunakan dan tidak sekadar menjelaskan temuan. Pembahasan harus diperkaya dengan merujuk hasil-hasil penelitian sebelumnya yang telah terbit dalam jurnal ilmiah.

\section{KESIMPULAN}

Berdasarkan hasil penelitian dan pembahasan dapat disimpulkan bahwa hipotesis, Youtube efektif sebagai media pembelajaran mata pelajaran PPKn pada masa pandemic Covid19 dapat diterima.

Hasil penelitian membuktikan bahwa pada masa pandemi Covid-19 Youtube lebih menarik bagi peserta didik. Youtube membantu peserta didik dalam memahami materi pelajaran meskipun melalui pembelajaran jarak jauh. Waktu belajar peserta didik lebih rileks atau santai dengan menggunakan media Youtube. Beban belajar peserta didik juga menjadi lebih ringan dengan menggunakan media Youtube.

\section{DAFTAR PUSTAKA}

Endang Soemantri. (2011). Pendidikan Karakter Nilai Inti Bagi Upaya Pembinaan Kepribadian Bangsa. Bandung : Aksara Press

Mabruri, Anton. (2010). Resistensi Gaya Hidup Teori dan Realitas. Yogyakarta : Jalasutra.

Rukiyati, dkk. (2013). Pendidikan Pancasila. Yogyakarta :UNY Press.

Suparlan Al Hakim, dkk. (2014). Pendidikan Kewarganegaraan Dalam Kontek Indonesia. Malang : Madani.

Indiani, B. (2020). Mengoptimalkan Proses Pembelajaran Dengan Media Daring Pada Masa Pandemi COVID - 19. JURNAL SIPATOKKONG BPSDM SULSEL, 1(3), 227-232. Retrieved from http://ojs.bpsdmsulsel.id/index.php/sipatokkong/article/view/55 . 